\section{Pulp Tissue Dissolution Capacity of Sodium Hypochlorite Combined with Cetrimide and Polypropylene Glycol}

Luiza Helena Silva de Almeida ${ }^{1}$, Natália Gomes e Silva Leonardo ${ }^{1}$, Ana Paula Neutzling Gomes ${ }^{1}$, Luciano Giardino², Erick Miranda Souza ${ }^{3}$, Fernanda Geraldo Pappen ${ }^{1}$

\author{
'Department of Semiology and \\ Clinics, School of Dentistry, \\ UNIPel - Federal University of \\ Pelotas, Pelotas, RS, Brazil \\ ${ }^{2}$ Department of Endodontics, School \\ of Dentistry, University of Torino, Italy \\ ${ }^{3}$ School of Dentistry, Florence \\ Institute, São Luis, MA, Brazil
}

Correspondence: Profa. Fernanda Geraldo Pappen, Rua Gonçalves Chaves, 457, 96015-560 Pelotas, RS, Brasil. Tel:+55-53-3225-6741. e-mail: ferpappen@yahoo.com.br

\begin{abstract}
This study evaluated the influence of the addition of cetrimide and polypropylene glycol to sodium hypochlorite $(\mathrm{NaOCl})$ on its capacity to dissolve pulp tissue. Bovine pulp fragments with standardized weight and volume were immersed for 5, 15 and $30 \mathrm{~min}$ in $2 \mathrm{~mL}$ of $\mathrm{NaOCl}$ and Hypoclean ( $\mathrm{NaOCl}$ added with cetrimide and polypropylene glycol) solutions at 5.25\%, 2.5\%, $1 \%, 0.5 \%$ and $0.25 \%$ and afterwards re-weighted. Distilled water was used as a control. The percentage of tissue loss was considered for statistical analysis (univariate ANOVA, SPSS, v. 17.0) at 5\% significance level. There was no tissue dissolution in the control group. $\mathrm{NaOCl}$ added with surfactants (Hypoclean) dissolved more pulp tissue $(p<0.05)$ than $\mathrm{NaOCl}$ alone. Tissue dissolution was directly dependent on the concentration of solutions $(p<0.05)$, and also on the time range $(p<0.05)$. The combination of $\mathrm{NaOCl}$ at high and low concentrations with the surfactants cetrimide and polypropylene glycol increased significantly its capacity to dissolve pulp tissue.
\end{abstract}

Key Words: pulp tissue dissolution, sodium hypochlorite, cetrimide, polypropylene glycol.

\section{Introduction}

Endodontic treatment failure may occur due to residual organic tissue or infected inorganic tissue left in the root canal after instrumentation (1). Various studies have reported inadequate root canal debridement regardless of the instrumentation technique $(2,3)$. Using the reliable microtomography method, a large number of untouched root dentin areas have been shown to remain after root canal instrumentation $(2,3)$. This deficient mechanical preparation highlights the debriding limitations of the current chemical-mechanical methods because it could offer an opportunity for microorganisms to recolonize the unfilled canal space, resulting in endodontic failure. Even sterile pulp tissue, if not completely removed, will possibly become a nutrient source to microorganisms (4).

Instruments and chemical irrigants are used in conjunction to achieve endodontic debridement. Sodium hypochlorite $(\mathrm{NaOCl})$ is the most widely employed solution, usually at concentrations ranging from $0.5 \%$ to $5.25 \%$. $\mathrm{NaOCl}$ presents a high tissue-dissolving capacity $(5,6)$ and a wide-spectrum antimicrobial activity (6). Nevertheless, despite the excellent tissue-dissolving capacity and antimicrobial activity, $\mathrm{NaOCl}$ presents a relative high surface tension $\left(48.90 \mathrm{~mJ} / \mathrm{m}^{2}\right)$. This high surface tension limits the penetration of the solution into canal irregularities and deep into the dentinal tubules (7), reducing the quality of the debridement produced by $\mathrm{NaOCl}$.

The capacity of surface-active agents (surfactants) to reduce the surface tension of $\mathrm{NaOCl}$ solutions has been demonstrated $(8,9)$. Hypoclean (Ogna Laboratori Farmaceutici, Milan, Italy) is a commercial detergent-based endodontic solution with low surface tension $(29.13 \mathrm{~mJ} /$ $\mathrm{m}^{2}$ ), which contains $5.25 \%$ sodium hypochlorite and two different surfactant agents: cetrimide and polypropylene glycol. In a recent study, Hypoclean showed an increased capacity to kill bacteria compared with a pure $5.25 \% \mathrm{NaOCl}$ solution (10). It is, however, unknown whether the addition of the surface modifiers cetrimide and polypropylene glycol interferes with $\mathrm{NaOCl}$ capacity to dissolve pulp tissue.

In the present study, an in vitro pulp dissolution assay was designed to verify the null hypothesis that there is no significant improvement in pulp tissue dissolution by Hypoclean compared with a pure $\mathrm{NaOCl}$ solution at different concentrations and after different contact times.

\section{Material and Methods}

\section{Solutions}

$\mathrm{NaOCl}$ and $\mathrm{NaOCl}$ combined with cetrimide and polypropylene glycol (Hypoclean) were obtained as $5.25 \%$ stock solutions (Ogna). The solutions were kept at $4{ }^{\circ} \mathrm{C}$ following the manufacturer's recommendations and brought to room temperature before use. The 5.25\% solutions were diluted in distilled water, immediately before use to obtain $2.5 \%, 1 \%, 0.5 \%$ and $0.25 \%$ solutions. Distilled water was used as control.

\section{Pulp Tissue Preparation}

Fresh extracted bovine incisors were stored at $-20^{\circ} \mathrm{C}$ 
until required. The animals were slaughtered for commercial purposes. The study did not, in any way, influence the premortal fate of the animals or the slaughtering process. Consequently, the institutional ethics committee approved the study (Process \# 23110.002848/2009-78).

For pulp extraction, teeth were left at room temperature to defrost. After resection of the root apical third in a precision cutting machine, pulp tissue was removed with small tweezers and washed in distilled water.

Bovine pulp samples were frozen and kept at $-27{ }^{\circ} \mathrm{C}$ in a covered 96 -well plate to prevent freeze-drying until further use. Immediately before the dissolution tests, each pulp was blotted dry and weighted using a precision scale in an air-tight container. Additionally, pulp fragments were divided using a scalpel to obtain tissue samples with similar size, shape, weight and volume ( $45 \pm 5 \mathrm{mg})$.

\section{Dissolution Test}

The previously weighed bovine pulp fragments were immersed in $2 \mathrm{~mL}$ of each concentration $(5.25 \%, 2.5 \%$, $1 \%$ and $0.5 \%$ ) of $\mathrm{NaOCl}$ and Hypoclean solutions, one fragment persolution. In the control group, pulp fragments were immersed in distilled water. Tests were done in triplicate. After 5, 15 and $30 \mathrm{~min}$ in the solutions, the bovine pulp fragments were blotted dry and re-weighed using a precision scale in an airtight container. The tests were performed at $32{ }^{\circ} \mathrm{C}$ to mimic the average intracanal temperature. The percentage of tissue loss from the original weight was calculated.

\section{Statistical Analysis}

Data were analyzed using a univariate analysis of variance (SPSS 16.0; SPSS Inc., Chicago, IL, USA), considering solutions, concentrations and time of contact as independent variables, and the percentage of tissue dissolution as the dependent variable. Tukey's HSD test was used for multiple comparisons within the solutions, concentrations and times of contact. The $\alpha$-type error was set at 0.05 .

\section{Results}

In the control group, no pulp tissue dissolution was observed after each evaluated time point. The mean percentage of tissue weight loss for each tested solution in different concentrations is shown in Table 1. The solutions, concentrations and contact times influenced significantly the percentage of tissue weight loss $(p<0.05)$.

Hypoclean, the $\mathrm{NaOCl}$ solution containing cetrimide and polypropylene glycol, presented significantly higher capacity of pulp tissue dissolution than conventional $\mathrm{NaOCl}$ solutions (Tukey HSD, $\mathrm{p}<0.05$ ). Conventional $\mathrm{NaOCl}$ dissolved a mean of $31.17 \%$ of tissue, while detergents combined with $\mathrm{NaOCl}$ increased this mean to $40.58 \%$ (Fig. 1).

A statistically significant raise in the percentage of pulp tissue dissolution was observed by increasing the concentration of both solutions $(p<0.05)$ (Fig. 2). The percentage of tissue weight loss was significantly different among the contact times. Weight loss was significantly greater after $30 \mathrm{~min}$ of contact than after $15 \mathrm{~min}$ and 5 $\min (p<0.05)$.

\section{Discussion}

In this study the pulp tissue dissolution capacity of $\mathrm{NaOCl}$ solutions combined or not with surfactants was assessed. Not only disinfection, but also debridement of root canals is an important step to be accomplished during endodontic therapy. The debridement quality can be influenced by the choice of chemicals used in association with root canal instrumentation. The current study reinforced the capacity of $\mathrm{NaOCl}$ to dissolve pulp tissue. The present results demonstrate that the addition of surfactants to $\mathrm{NaOCl}$ solution (Hypoclean) is able to improve its tissue-dissolving action.

The capacity of pulp tissue dissolution is expected from an endodontic irrigant because any pulp remnant left in the root canal system may be responsible for root canal treatment failure (11). In addition, postoperative pain after pulpectomy may be associated with pulp tissue remains in the root canal (12).

Different organic tissues have been used to test $\mathrm{NaOCl}$ tissue-dissolving capacity (11). Porcine and bovine muscle $(7,13)$, rabbit liver (1), rat connective tissue (14), pig mucosa (5), and bovine pulp tissue (15) have been

Table 1. Mean and standard deviation of pulp tissue weight loss (\%) for each solution at the different concentrations after each contact time

\begin{tabular}{lccc}
\hline Solution & $5 \mathrm{~min}$ & $15 \mathrm{~min}$ & $30 \mathrm{~min}$ \\
\hline NaOCl 0.25\% & $1.48 \pm 1.91$ & $1.41 \pm 1.93$ & $1.11 \pm 1.92$ \\
Hypoclean 0.25\% & $10.70 \pm 9.20$ & $12.28 \pm 10.18$ & $6.17 \pm 3.82$ \\
& $5.07 \pm 5.14$ & $16.01 \pm 7.29$ & $20.64 \pm 6.15$ \\
$\mathrm{NaOCl} 0.5 \%$ & $13.38 \pm 8.83$ & $26.98 \pm 12.13$ & $29.68 \pm 9.36$ \\
Hypoclean 0.5\% & $21.21 \pm 10.90$ & $29.77 \pm 8.87$ & $40.29 \pm 0.49$ \\
& $25.93 \pm 3.22$ & $43.02 \pm 9.29$ & $54.62 \pm 2.01$ \\
$\mathrm{NaOCl} 1 \%$ & $17.38 \pm 8.80$ & $51.11 \pm 4.92$ & $61.79 \pm 11.80$ \\
Hypoclean 1\% & $45.01 \pm 8.70$ & $66.29 \pm 8.58$ & $69.64 \pm 18.14$ \\
NaOCl 2.5\% & & & \\
Hypoclean 2.5\% & & $68.38 \pm 8.29$ & $84.88 \pm 7.43$ \\
NaOCl 5.25\% & $47.07 \pm 11.66$ & 0 & 0 \\
Hypoclean 5.25\% & $54.61 \pm 14.86$ & $67.66 \pm 24.29$ & $82.75 \pm 7.80$ \\
$\mathrm{H}_{2} \mathrm{O}$ & 0 & & \\
\hline
\end{tabular}


the most commonly used samples to evaluate organic tissue dissolution capacity of different solutions. Human dental pulp, even though being an ideal testing tissue, is not easily retrieved, and presents limitations for sample standardization (7), in addition to all ethical issues involved. According to Naenni et al. (5) and Zehnder et al. (6), porcine mucosal tissue is a dense tissue, with a high content of connective tissue fibres. Consequently, it takes a hypochlorite solution approximately three times longer to completely dissolve the porcine palatal tissue compared with pulp tissue $(5,6)$. Bovine pulp tissue is more comparable to human pulp than other animal tissues and has been previously used to test the dissolution capacity of different endodontic irrigants (15).

The association between $\mathrm{NaOCl}$ dissolving capacity and the solution concentration, volume, $\mathrm{pH}$, temperature, time of contact with tissues, in addition to the type, volume and mass of the organic tissue has already been described $(1,14)$. Therefore, in the present study, these factors were rigorously standardized by using the same volume of $\mathrm{NaOCl}$ at a constant temperature and pulp tissue of approximately the same shape and weight.

Some studies tested the capacity of solutions in dissolving organic tissues using methodologies that evaluate the velocity or the time spent for complete dissolution of tissue fragments $(11,15)$. In the present study, the weight of pulp tissue was measured on a precision scale before and after its contact with the irrigating solutions. This method is more accurate because the determination of the endpoint of complete pulp tissue dissolution depends on human view and training, and it is difficult to be established because of the large number of bubbles that are formed
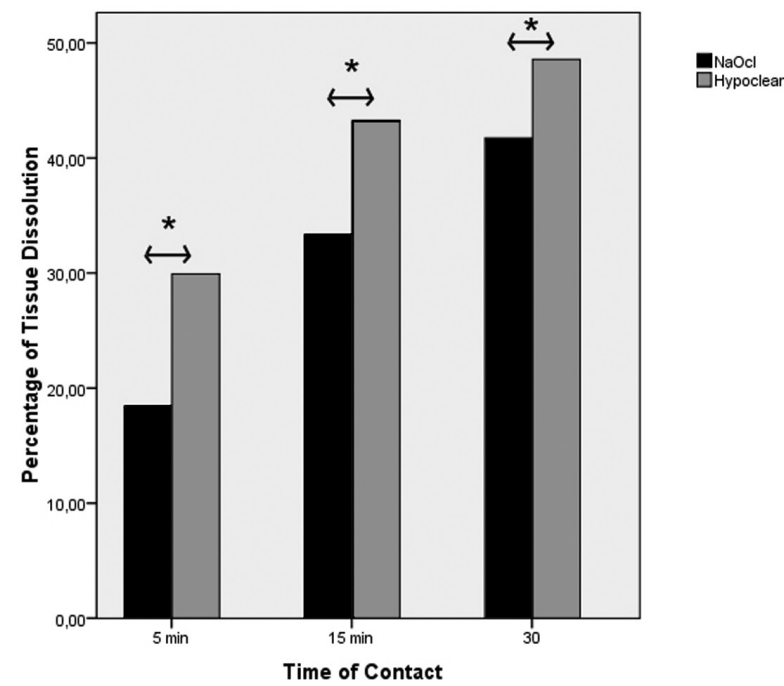

Figure 1. Mean percentage of tissue dissolution for $\mathrm{NaOCl}$ and Hypoclean after each contact time. The percentage tissue dissolution of solutions was significantly different at each time range. during the saponification reaction (7).

The results of this study agree with those of previous studies in which $\mathrm{NaOCl}$ showed good tissue dissolution capacity $(5,6,15)$. In the same way as found by Okino et al. (15), the capacity of $\mathrm{NaOCl}$ in dissolving pulp tissue is significantly enhanced by increasing the concentration of $\mathrm{NaOCl}$ solution. The tissue-dissolution capacity of $\mathrm{NaOCl}$ solutions occurs due to their available chlorine $(\mathrm{OCI} / \mathrm{HOCl})$ (6). Thus, $\mathrm{NaOCl}$ solutions at higher concentrations present higher levels of free chlorine. However, some authors advocate that $0.5 \%$ and $1 \% \mathrm{NaOCl}$ are safer than $\mathrm{NaOCl}$ at higher concentrations, as $1 \% \mathrm{NaOCl}$ has been shown to produce cytotoxic effects and inflammatory reactions if it reaches the periapical tissue (16). As $\mathrm{NaOCl}$ at low concentrations presents lower capacity to dissolve pulp remnants (15), the addition of detergents like cetrimide and polypropylene glycol could increase its tissue-dissolution capacity in root canal irrigation, while maintaining the low cytotoxicity of the solution.

Clarkson et al. (11) also tested the addition of surfactants to $\mathrm{NaOCl}$. These authors tested an Australian product for domestic use containing $5 \% \mathrm{NaOCl}$ and a detergent and found that this combination enhanced the capacity of $\mathrm{NaOCl}$ to dissolve organic tissues, in the same way as in the present study. Moreover, Stojicic et al. (7) confirmed these findings and reported that the better performance of $\mathrm{NaOCl}$ with surfactants, in comparison with $\mathrm{NaOCl}$ alone, in the same concentration, remains when it is diluted, heated or agitated. According to those authors (7), the

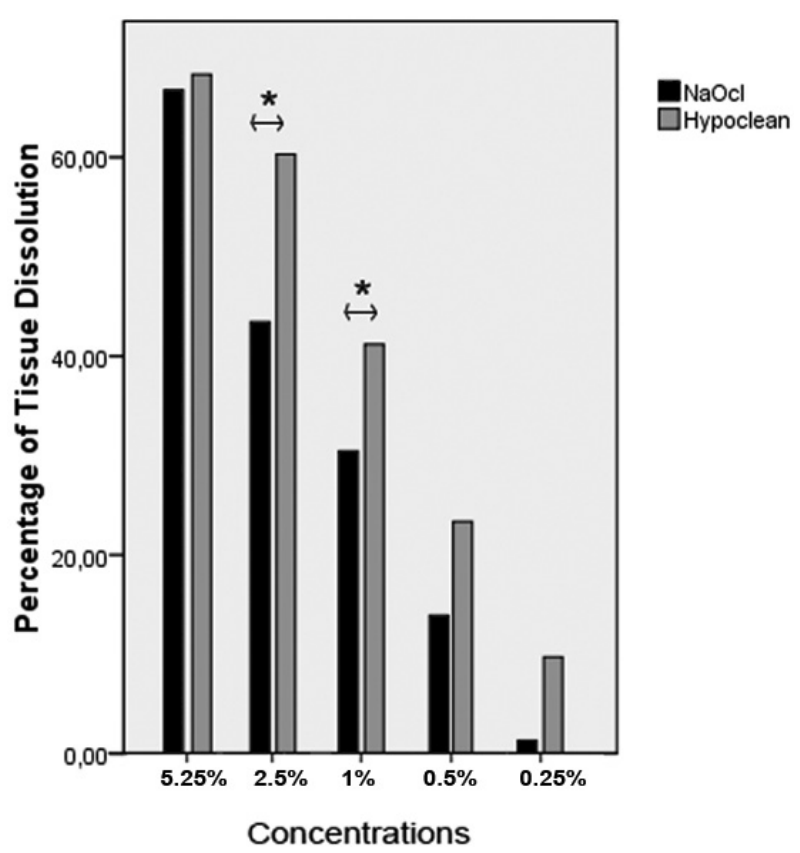

Figure 2. Mean percentage of tissue dissolution for $\mathrm{NaOCl}$ and Hypoclean considering the different concentrations of both solutions. 
greater capacity of $\mathrm{NaOCl}$ in dissolving organic tissue in presence of surfactants probably occurs due to presence of the surface active agent, which allows a better contact on the surface of the tissues, as well as a faster exchange with fresh solution. Several authors have claimed that the addition of surfactants to different solutions may improve their properties. Cameron et al. (17) suggested the addition of a fluorocarbon surfactant to $\mathrm{NaOCl}$ in order to obtain low surface tension, and Yilmaz et al. (18) affirmed that the addition of surface modifiers to 17\% EDTA could significantly decrease its surface tension, resulting in better wetting of dentin. Xiao et al. (19) suggested the addition of surfactants to enhance NaOCl's disinfection efficacy, and Pappen et al. (20) confirmed that cetrimide could improve the antimicrobial properties of different solutions. Chlorhexidine gluconate also demonstrated a higher efficacy when combined with wetting agents and surface modifiers. It has been reported that CHX-Plus, a digluconate solution combined with surfactants, killed biofilm faster than $\mathrm{CHX}$ alone, in the same concentration $(8,21)$.

Clinically, the better capacity of irrigants combined with surfactants to penetrate in the complex root canal anatomy, combined with the increased efficacy in tissue dissolution can also be a better capacity for root canal debridement and decontamination. However, it should be considered that in the current methodology, $\mathrm{NaOCL}$ solutions were placed in contact with organic tissue, without the presence of dentin. In the presence of dentin, it could be expected contrasting tissue dissolution results due to the more reliable reproduction of clinical situation. The composition of dentin is closely similar to that of bone apatite, which, due to the high concentration of carbonate, provides a buffering effect for all acid-base disturbances (22). Dentin has also been described as presenting a considerable buffering effect against acids and alkali (23). The inactivation of the antimicrobial properties of endodontic medications by the chemical environment of root canal has already been described (24), and the diminished tissue dissolving capacity of $\mathrm{NaOCl}$ in presence of dentin has also been reported recently (25). Further studies are required to evaluate the influence of these surfactants on the pulp tissue dissolving capacity of $\mathrm{NaOCl}$ using a dentin model.

In conclusion, under the tested conditions, the addition of the surfactants cetrimide and polypropylene glycol to $\mathrm{NaOCl}$ at high and low concentrations increased significantly its capacity to dissolve bovine pulp tissue.

\section{Resumo}

Este estudo avaliou a influência da adição de cetramida e polipropilenoglicol ao hipoclorito de sódio (Hypoclean) na capacidade de dissolução pulpar do hipoclorito de sódio ( $\mathrm{NaOCl}$ ). Fragmentos de tecido pulpar bovino, com peso e volume padronizados foram imersos por períodos de 5, 15 e 30 min em $2 \mathrm{~mL}$ de $\mathrm{NaOCl}$ ou Hypoclean nas concentrações 5,25\%, 2,5\%, $1 \%, 0,5 \%$ e $0,25 \%$. Após a imersão nas soluções testadas, os fragmentos foram novamente pesados. Como controle, foi utilizada água destilada. 0 percentual de perda tecidual foi considerado para análise estatistica (ANOVA univariada, SPSS, v. 17.0). Não houve dissolução tecidual no grupo controle. A solução de $\mathrm{NaOCl}$ combinada a surfactantes (Hypoclean) dissolveu um maior percentual de tecido pulpar $(p<0,05)$ que o $\mathrm{NaOCl}$ sem associações. A dissolução tecidual foi diretamente dependente da concentração das soluções $(p<0,05)$, assim como do tempo de exposição às soluções $(p<0,05)$. A adição dos surfactantes cetramida e polipropilenoglicol ao $\mathrm{NaOCl}$ em concentrações altas e baixas aumentou significativamente sua capacidade de dissolução do tecido pulpar.

\section{References}

1. Moorer WR, Wesselink PR. Factors promoting the tissue dissolving capability of sodium hypochlorite. Int Endod J 1982;15:187-196.

2. Paqué $F$, Peters $O A$. Micro-computed tomography evaluation of the preparation of long oval root canals in mandibular molars with the self-adjusting file. J Endod 2011;37:517-521.

3. Peters $\mathrm{OA}$, Boessler $\mathrm{C}$, Paqué F. Root canal preparation with a novel nickel-titanium instrument evaluated with micro-computed tomography: canal surface preparation over time. J Endod 2010;36:1068-1072.

4. Love RM. Enterococcus faecalis: a mechanism for its role in endodontic failure. Int Endod J 2001;34:399-405.

5. Naenni N, Thoma K, Zehnder M. Soft tissue dissolution capacity of currently used and potential endodontic irrigants. J Endod 2004;30:785-787.

6. Zehnder M, Kosicki D, Luder H, Sener B, Waltimo T. Tissue-dissolving capacity and antibacterial effect of buffered and unbuffered hypochlorite solutions. Oral Surg Oral Med Oral Pathol Oral Radiol Endod 2002;94:756-762.

7. Stojicic S, Zivkovic S, Qian W, Zhang H, Haapasalo M. Tissue dissolution by sodium hypochlorite: effect of concentration, temperature, agitation, and surfactant. J Endod 2010;36:1558-1562.

8. Williamson AE, Cardon JW, Drake DR. Antimicrobial susceptibility of monoculture biofilms of a clinical isolate of Enterococcus faecalis, J Endod 2009;35:95-97.

9. Mohammadi Z, Mombeinipour A, Giardino L, Shahriari S. Residual antibacterial activity of a new modified sodium hypochloritebased endodontic irrigation solution. Med Oral Patol Oral Cir Bucal 2011;16:588-592.

10. Giardino L, Ambu E, Becce C, Rimondini L, Morra M. Surface tension comparison of four common root canal irrigants and two new irrigants containing antibiotic. J Endod 2006;32:1091-1093.

11. Clarkson RM, Moule AJ, Podlich $H$, Kellaway $R$, Macfarlane $R$, Lewis $D$, et al.. Dissolution of porcine incisor pulps in sodium hypochlorite solutions of varying compositions and concentrations. Austr Dent J 2006:51:245-251.

12. Abou-Rass M, Oglesby SW. The effects of temperature, concentration, and tissue type on the solvent ability of sodium hypochlorite. J Endod 1981;7:376-377.

13. Hasselgren G, Olsson B, Cvek M. Effects of calcium hydroxide and sodium hypochlorite on the dissolution of necrotic porcine muscle tissue. J Endod 1988;14:125-127.

14. Hand RE, Smith ML, Harrison JW. Analysis of the effect of dilution on the necrotic tissue dissolution property of sodium hypochlorite. J Endod 1978;4:60-64.

15. Okino LA, Siqueira EL, Santos M, Bombana AC, Figueiredo JA. Dissolution of pulp tissue by aqueous solution of chlorhexidine digluconate and chlorhexidine digluconate gel. Int Endod J 2004; 37:38-41.

16. Pashley EL, Birdsong NL, Bowman K, Pashley DH. Cytotoxic effects of $\mathrm{NaOCl}$ on vital tissue. J Endod 1985;11:525-528.

17. Cameron JA. The effect of a fluorocarbon surfactant on the surface tension of the endodontic irrigant, sodium hypochlorite. A preliminary report. Aust Dent J 1986;31:364-368.

18. Yilmaz Z, Basbag B, Buzoglu HD, Gümüsderelioglu M. Effect of low- 
surface-tension EDTA solutions on the wettability of root canal dentin. Oral Surg Oral Med Oral Pathol Oral Radiol Endod 2011;111:109-114.

19. Xiao D, Ye R, Davidson PM, Golden DA, Zhong Q. Sucrose monolaurate improves the efficacy of sodium hypochlorite against Escherichia coli 0157:H7 on spinach. Int J Food Microbiol 2011;145:64-68.

20. Pappen FG, Shen Y, Qian W, Leonardo MR, Giardino L, Haapasalo M. In vitro antibacterial action of Tetraclean, MTAD and five experimental irrigation solutions. Int Endod J 2010;43:528-535.

21. Shen Y, Qian W, Chung C, Olsen I, Haapasalo M. Evaluation of the effect of two chlorhexidine preparations on biofilm bacteria in vitro: a three dimensional quantitative analysis. J Endod 2009;35:981-985.

22. Poyart $\mathrm{CF}$, Bursaux $\mathrm{E}_{1}$ Freminet $\mathrm{A}$. The bone $\mathrm{CO}_{2}$ compartment: evidence for a bicarbonate pool. Respir Physiol 1975;25:89-99.

23. Wang JD, Hume WR. Diffusion of hydrogen ion and hydroxyl ion from various sources through dentine. Int Endod J 1988;21:17-26.

24. Haapasalo HK, Sirén EK, Waltimo TM, Ørstavik D, Haapasalo MP. Inactivation of local root canal medicaments by dentine: an in vitro study. Int Endod J 2000;33:126-131.

25. Slutzky-Goldberg I, Hanut A, Matalon S, Baev V, Slutzky H. The effect of dentin on the pulp tissue dissolution capacity of sodium hypochlorite and calcium hydroxide. J Endod 2013;39:184-188.

Received July 27, 2012 Accepted August 16, 2013 